\title{
FLOOD RISK FACTORS IN SUBURBAN AREA IN THE CONTEXT OF CLIMATE CHANGE ADAPTATION POLICIES - CASE STUDY OF WROCLAW, POLAND
}

\author{
Szymon Szewrański', Jan Kazak', Marta Szkaradkiewicz', ,Józef Sasik \\ ' Department of Spatial Economy, Wroclaw University of Environmental and Life Sciences, Grunwaldzka 53, \\ 50-357 Wrocław, Poland, e-mail: szymon.szewranski@up.wroc.pl; jan.kazak@up.wroc.pl; marta.szkaradkie- \\ wicz@up.wroc.pl
}

Received: 2014.11.21

Accepted: 2015.02.04

Published: 2015.04.01

\begin{abstract}
The uncontrolled sprawl of urban development exerts environmental impact in rural areas. The aim of this study is to identify areas vulnerable to climate change in the context of implementation of policies adapting to climate change at the local level. Such areas can be defined as those where the negative implication of flesh flood overlapping with soil sealing is observed. The study areas composed of municipalities which are influenced by the urban sprawl process of the city of Wroclaw, Poland. The analyses were performed using publicly available spatial data from aerial orthophotomaps from 2004-2012, the satellite images; archival and current land use maps. The database CORINE 1990, 2000, 2006; Urban Atlas and geodatabase of the European Environment Agency were also of an important usage for this study.
\end{abstract}

Keywords: climate change adaptation, water management, flood risk, soil sealing.

\section{INTRODUCTION}

The main climatic factors of floods, among other, include precipitation (volume of rainfall, its intensity and duration) or air temperature (especially important for the formation of winter floods) [Kundzewicz 2014]. Whereas the non-climatic factors include catchment topography, slopes, soil type, land use, density of the river network, etc. [De Roo et al. 2003, 2001]. Analysis of these conditions is necessary in order to correctly identify areas vulnerable to climate change, which in the case of Polish include mainly floods and droughts.

Historical records and ongoing hydro-meteorological observations prove that there have been approx. 90 recorded floods in Oder river basin (an average of 1 over 10 years). Most of them were small floods. Big floods occurred less frequently [Dubicki et al. 2005]. Floods were not significantly limited by hydro-technical treatments (river training, levees, flood-control reservoirs etc.). The size of economic and social losses was often the result of improper land management in the catchment area.
Flood events are expected to increase in the future [Falloon and Betts 2010]. Integrated management of water resources requires the development strategy of both mitigation and adaptation to upcoming changes in the environment. The choice of the mitigation and adaptation solution depends on the availability of economic resources and social acceptance [Kundzewicz and Matczak 2012].

\section{MATERIALS AND METHODS}

The research area consists of the city of Wroclaw and rural municipalities near Wroclaw: Kostomłoty, Miękinia, Oborniki Slaskie, Wisznia Mała, Czernica, Długołęka, Katy Wroclaw, Kobierzyce, Siechnice and Żórawina. Within these administrative bodies, 266 cadastral units were carefully investigated. The analyses were performed using publicly available spatial data from aerial orthophotomaps from 2004-2012, the satellite images; archival and current land use maps. The database CORINE 1990, 2000, 2006; Urban Atlas and geodatabase of the European Environment 
Agency were also of an important usage for this study. Having the above sources analysed, changes in land use in the suburban area of Wrocław from 1990 to 2006 were identified. The analyses were performed using open GIS systems. The area covered by the study is subject to strong structural and spatial transformations. Spreading residential zone, increasing the number of investments in infrastructure and new industrial facilities have caused changes in the quality of the natural environment [Szewranski et al. 2013].

The holistic analysis of the precipitation, microclimate and hydrological conditions can be useful in choosing the location of investments in the context of adaptation to climate change. These conditions were compared with the current trends in the spatial development of real estates. The conclusions of these studies enable answering the question whether the current planning system requires more intense inclusion of an environmental impact assessment of the policy. Such analyses seem to be necessary in the context of the implementation of The National Strategy for Adaptation to Climate Change 2020 [SAP2020].

\section{RESULTS}

In order to identify the cadastral units where the risk of flooding is greatest, hydrological maps based on floods' greatest spatial distribution in the case study area have been investigated (Figure 1).
The greatest risk of flooding occurs in the Odra valley, particularly in the area of the city of Wroclaw, due to large amount of water (cadastral unit: Wroclaw, Paniowice, Kotowice, Blizanowice-Trestno) and numerous tributaries of the river. The smallest number of areas being at risk of flooding are located in the valley of the river Ślęza (cadastral units: Wroclaw, Żerniki Great Galowice), a bit more in the valley of the Bystrzyca (cadastral units: Wroclaw, Samotwór, Skalka, Romnów, Sadowice, Krobielowice, Gniechowice, Zachowice, Kamionna and Czereńczyce) and the largest in the catchment of the Olawa (cadastral units: Wroclaw, Mokry Dwór, Groblice, Zębice, Grodziszów, Siechnice-Prawocin, Święta Katarzyna) and the Widawa (cadastral units: Szymanów, Psary, Krzyżanowice, Wilczyce, Wroclaw).

This can be explained by downslopes of each sub-catchment and soil permeability. If the downslopes are larger and soils are more compact peak flow occurs faster. That was a cause which triggered the fact that such a wave usually occurs much earlier in the area of Wroclaw, than in the Oder River. There were two main reasons for the catastrophic floods in the Odra River in July 1997: an intense flow of water and impeded drainage of water.

The average annual precipitation in the study area is about $550-660 \mathrm{~mm}$. A flood type that prevails in the Oder River is widespread rainfall floods caused by prolonged rains of large scale and considerable intensity. A flood type in the

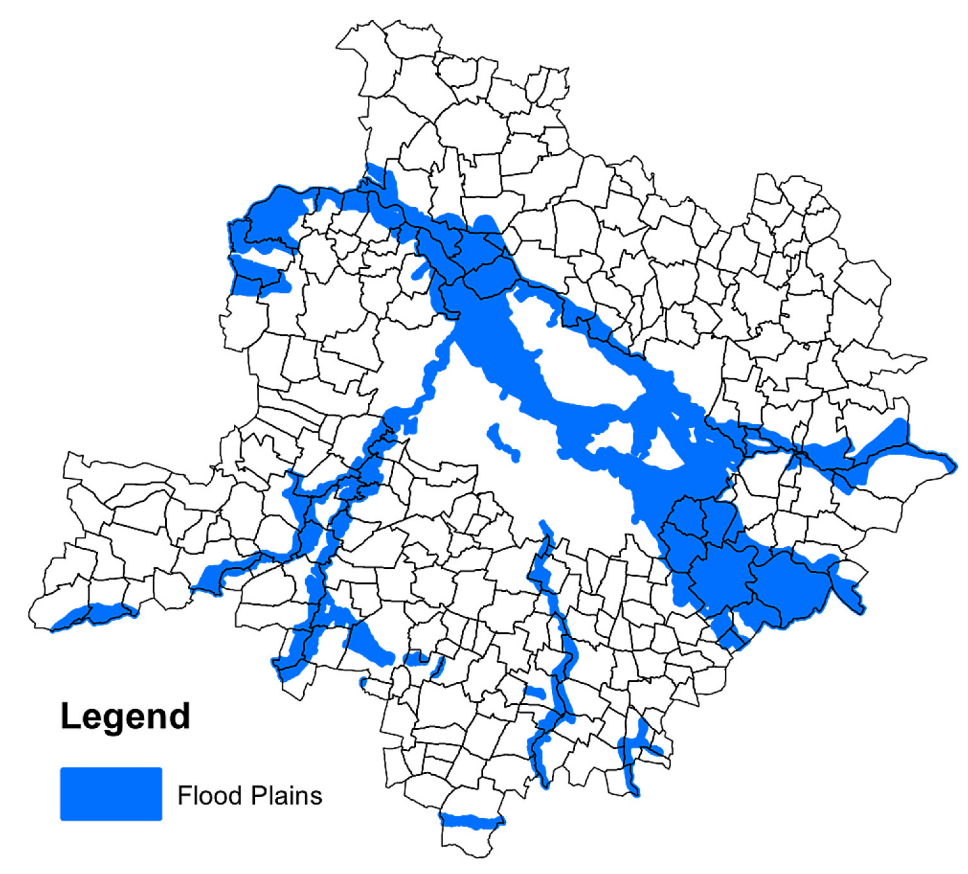

Figure 1. Flood plains in the case study area 
tributaries of the Oder River (river: Bystrica, Olawa, Ślęza, Widawa, etc.) is of torrential rainfall caused among many factors by convective storms in river basins. When analysing the effect of precipitation on flood creation one should take into consideration not only annual, monthly or ten-day sums but also their distribution in time and space. In the study area there are rarely embolic type of flooding caused by local rising due to ice floes.

It is assumed that by 2030 , the biggest threat to the economy and society will be extreme weather and climate (torrential rains, flooding, landslides, heat waves, droughts, hurricanes, etc.). These phenomena will occur with increasing frequency and intensity, and will cover more and more areas of the country. In the case study area heavy precipitation will increase in the first half of the summer, with intensities exceeding $5 \mathrm{~mm} / \mathrm{min}$, with a probability of $\geq 10 \%$. The change in precipitation patterns meaning a rapid increase in the number of days with high intensity precipitation (daily precipitation $\geq 50 \mathrm{~mm}$ for 2 days/decade (SAP2020, 2013) will occur on the majority of the land in Poland (including the study area).

Climatic conditions of Wroclaw exhibits characteristics typical of large urban and industrial agglomerations, where the impact of the economic activity is reflected by a change in the physical characteristics of the surface, air pollution and artificial heat emission produced in municipal and industrial processes. Whereas nonurbanized areas are characterized by significant deviations of particular climate components - in particular precipitation and temperature. The increased rainfalls in Wroclaw were identified for the city centre, the Old Town and Karłowice and less intensive rainfall in the eastern districts (Biskupin, Swojec), as well as western - the average annual total precipitation is about $30-50 \mathrm{~mm}$ larger [Schmuck 1967].

The study area can be characterized by the average annual temperature of approx. $8.5^{\circ} \mathrm{C}$, and the duration of the growing season is 220 days, predominate winds from the west. Fairly high temperatures during the winter half-year time result in rare spring embolic flooding causing the water daming on ice or snow jam. The greatest effect of air temperature can be observed during the formation of the summer floods. For the last thirty years there has been an increase in air temperature (with the exception that it is much stronger in winter and weaker in summer). Among the adverse harmful thermal effects to the environment, society and economy, severe heat waves must be mentioned (continuous days with daily maximum temperature $\geq 30{ }^{\circ} \mathrm{C}$ persisting for at least 3 days) and hot days (the temperature $\geq 30{ }^{\circ} \mathrm{C}$ ), the most common in the region of south-western part of the Poland.

In comparison to suburban are, solar radiation in Wroclaw is weakened, the number of hours of sunshine reduced, night cooling is less intense. The result is an increase of air temperature, known as the urban heat island, which is easily recognised during clear nights in summer when there is more than $5^{\circ} \mathrm{C}$. The average annual relative humidity in the city centre is approx. $6 \%$ lower than outside the city during clear nights in the summer by up to $40 \%$.

The geological structure and terrain affect the development of the river network, and indirectly the development of hydrographical networks and the formation of river floods. Areas which have a large river network density are characterized by high rainfall, low evaporation losses, varied terrain and impermeable surface.

From the hydrological point of view, the most important geological and soil factor that has got impact on the formation of the outflow is the permeability of the ground. This feature determines the seepage of rainwater and depends on the constant physical properties of the soil. The phenomenon which is very important is the growth of built-up areas, especially in urban areas. This is done at the expense of green spaces, reducing the area of land covered with natural cover. Wroclaw in hydrological terms resembles a mountain basin, where because of the intensive real-estate development, increased runoff occurs (Figure 2).

Cadastral units with the highest soil sealing (above 5\%) are Wilkszyn, Jeszkowice, SośnicaRóżaniec, Ratowice, Żórawina, Łany, Pietrzykowice-Rybnica, Suchy Dwór, Nowa Wieś Kącka, Szymanów, Tyniec Mały, Biestrzyków-Radomierzyce, Mokronos Dolny, Wilczyce, Czernica, Iwiny, Nowa Wieś Wrocławska, Psary, Gajków, Święta Katarzyna, Kobierzyce, Ślęza, Kamieniec, Pustków Żurawski, Wysoka, Rolantowice, Oborniki Śląskie, Smolec, Kiełczów, SiechnicePrawocin, Żerniki Wrocławskie, Mirków, Radwanice, Długołęka, Kąty Wrocławskie, Bielany Wrocławskie, Biskupice Podgórne. The vast majority of these areas are located in the Wroclaw county, south and east of the centre of Wroclaw.

In hydrological practice, a parameter characterizing the permeability of the basin is mostly 


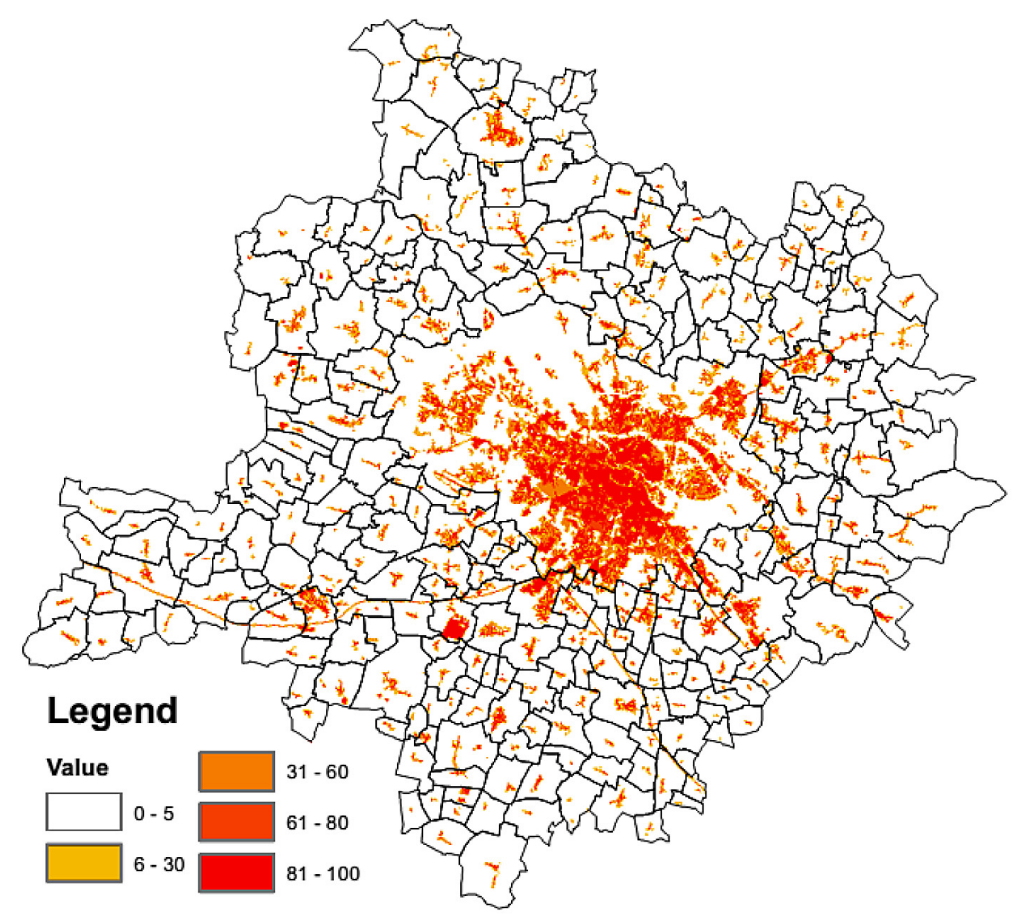

Figure 2. Soil sealing in \% [European Environment Agency]

expressed by density of the river network. On permeable soils river network is poorly developed because there are good conditions for infiltration. There are not small, periodically drying up watercourses, but there are large streams leading water during low periods. Infiltration is low in catchments with impervious surface, which increases surface runoff. In research process the length of the watercourses and the density of the river network in the selected cadastral units were analysed. The results showed that the longest watercourses occurs in the area of Wroclaw and much less in the catchments inflowing to the Oder River. If that was calculated per unit area, it gives the standard density of a river network of $0.8 \mathrm{~m} / \mathrm{m}^{2}$. The highest density occurs in the Odra valley, a bit smaller in the catchment of Widawa and definitely the lowest in the basins of Bystrica and Ślęza.

The factor that had a significant influence on the runoff formation and its distribution over time is land cover. The biggest impact on runoff catch play forests, that by increasing the roughness of the surface, cause a reduction in the rate of runoff and facilitate infiltration. Moreover, forests retard the process of snow melting which increases the retention capacity of the catchment. The forest cover in the case study area is lower than the national average, which affects the formation of flood. There is, however, a relatively large proportion of orchards in the areas. Low degree of for- est cover in the study area is caused by the high quality soils turned into arable land, which have smaller impact on the runoff catch. Runoff volume depends on the type of crop, development stages of plants and applied agrotechnical treatments.

When suburbian districts spring up rapidly and new infrastructure is being built the share of impervious surface is growing, which increases the risk of floods. In terms of surface area the largest new Urban Morpholocial Zone (UMZ) zones were created in 1990-2006 at the borders of districts: Kamieniec, Kotowice, Zacharzyce, Bielany Wrocławskie, Łany, Radwanice, Iwiny, Blizanowice-Trestno, Biestrzyków-Radomierzyce, Wilczyce, Krzeptów, Mirków, Żerniki Wrocławskie, Dobrzykowice, Wysoka, Krępice, Domaszczyn, Paniowice, Psary, Zabrodzie, Brzezina, Wróblowice, Szymanów, Biskupice, Lutynia, Wilkszyn, Mokronos Dolny, Krzyżanowice, Mokronos Górny, Galów, Ramiszów, Smolec. Newly builtup areas are also more vulnerable to the phenomenon of flash floods. It is assumed that areas vulnerable to climate change could be characterised by both high risk of flooding and excessive soil sealing (Figure 3).

Identified cadastral units are located where the impact of suburbanization is very high and at the same time flood risk. Beside Wrocław city there are: Szymanów, Psary, Wilczyce, SiechnicePrawocin as well as Święta Katarzyna. 


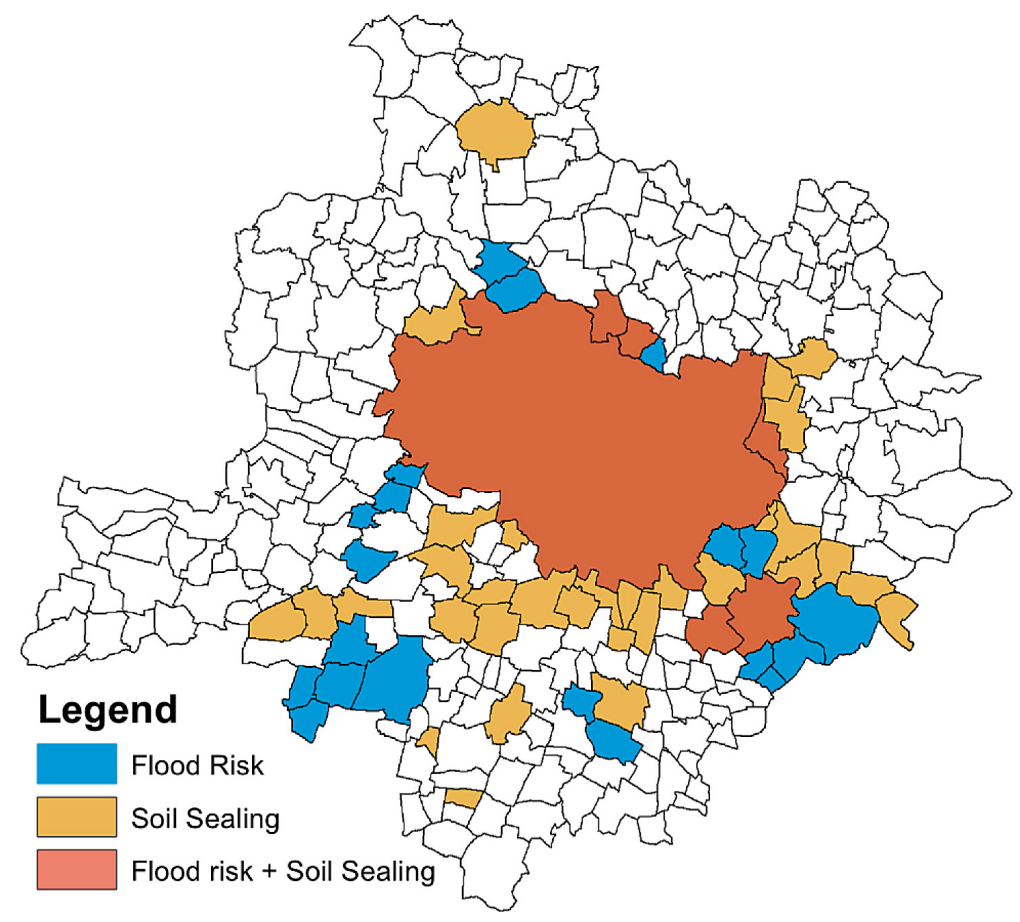

Figure 3. Cadastral units vulnerable to climate change because of high flood risk and excessive soil sealing

\section{CONCLUSIONS}

Changing climate conditions will have an impact not only on the size and availability of water resources, but also on the frequency and extent of flooding. The SAP2020 includes the analysis of the loss and cost of removing the damage caused by climate change. It proves that the phenomena that might cause the greatest damage in Poland are mainly related to floods. This problem applies to all sectors of the economy, especially to infrastructure located in the floodplain. Floods in small scale happen every year and cause losses of 0,08 $0,1 \%$ of GDP. Once a dozen or so years, however, flooding appears causing above-average losses valued respectively of 0.5 and $0.9 \%$ of GDP.

It is, though, extremely important to adopt such an approach to the spatial management that assess the impact and minimize the risk and socio-economic losses of investments in early stage of their planning. Proper location of public or private investment should correspond to contemporary environmental challenges too. New development projects should be planned in a way to minimize negative impacts on the environment (e.g. the impact of soil sealing on water infiltration).

It is assumed that in order to be fully efficient spatial planning and water management should be integrated. Investments in water management infrastructure (including flood control activities) may not be only an addition to the spatial development plans. On the contrary, future solutions should be integrated, multicriterial and strategic. Development of flood protection programs should begin by setting priorities: protection of big cities, protection of agricultural land, etc. After determining the hierarchy of objectives, protective and adaptation measures could be addressed. The aim should be to integrate the activities of water management, spatial planning and environmental protection. It is necessary to limit the losses and compensate for lost benefits for those most affected by the implementation of the plan. In order to achieve that, it is vital to establish a strategy for plan implementation, indicate responsible actors and set indicators to monitor and evaluate the objectives' fulfilment.

\section{Acknowledgments}

The study was carried out in the framework of the research project NCN No. N N305 384838 "Indicator-based assessment of environmental changes caused by unsustainable sprawl of large cities".

\section{REFERENCES}

1. De Roo, A., Odijk, M., Schmuck, G., Koster, E., Lucieer, A., 2001. Assessing the effects of land use changes on floods in the meuse and oder catch- 
ment. Phys. Chem. Earth Part B Hydrol. Oceans Atmosphere 26, 593-599.

2. De Roo, A., Schmuck, G., Perdigao, V., Thielen, J., 2003. The influence of historic land use changes and future planned land use scenarios on floods in the Oder catchment. Recent Dev. River Basin Res. Manag. 28, 1291-1300.

3. Dubicki, A., Malinowska-Małek, J., Strońska, K., 2005. Flood hazards in the upper and middle Odra River basin - A short review over the last century. 11th Magdebg. Semin. Oct. 2004 Waters Cent. East. Eur. Assess. Prot. Manag. 35, 123-131.

4. Falloon, P., Betts, R., 2010. Climate impacts on European agriculture and water management in the context of adaptation and mitigation-The importance of an integrated approach. Spec. Sect. Integrating Water Agric. Manag. Clim. Change 408, 5667-5687.
5. Kundzewicz, Z.W., 2014. Adapting flood preparedness tools to changing flood risk conditions: the situation in Poland. Oceanologia 56, 385-407.

6. Kundzewicz, Z.W., Matczak, P., 2012. Natural risks: mitigation and adaptation. Ecohydrol. Hydrobiol. 12, 3-8.

7. Schmuck, A., 1967. Wpływ miasta na opady atmosferyczne (na przykładzie Wrocławia). Przegląd Geofiz. 12 (20), 293-310.

8. SAP2020, 2013. The National Strategy for Adaptation to Climate Change 2020. Poland.

9. Szewranski, S., Kazak, J., Sasik, J., 2013. Suburbanisation processes and their environmental effects in a zone of uncontrolled spread of a large city. Prace Naukowe Uniw. Ekon. we Wrocławiu, 170-179. 